\title{
A Randomized Study of Biomimetic Peptides Efficacy and Impact on the Growth Factors Expression in the Hair Follicles of Patients with Telogen Effluvium
}

\author{
Alexey Alekseevich Kubanov ${ }^{1,2}$, Yulia Albertovna Gallyamova ${ }^{1, *}$, Olga Andreevna Korableva ${ }^{2}$ \\ ${ }^{1}$ Department of Dermatovenereology and Cosmetology, Russian Medical Academy of Continuous Professional Education, Moscow, Russia. \\ ${ }^{2}$ State Research Center of Dermatovenereology and Cosmetology Ministry of Healthcare of the Russian Federation, Moscow, Russia.
}

\section{ARTICLE INFO \\ Article history: \\ Received on: 07/07/2017 \\ Accepted on: 20/11/2017 \\ Available online: 29/04/2018}

\section{Key words:}

hair loss, telogen effluvium, hair follicle, hair cycle, hair growth, growth factors, peptides.

\begin{abstract}
Currently, biomimetic peptides have been developed to treat alopecia, which consists of amino acid residues and are able to selectively interact with cell receptors. This article studies the expression of growth factors (VEGF, KGF, EGF, TGF- $\beta 1$ ) in the hair follicle of patients with telogen effluvium and healthy individuals and evaluating the efficacy of therapy with biomimetic peptides in patients with telogen effluvium based on clinical data and the dynamics. The method of immunofluorescence study of scalp specimens, which is taken by the punch biopsy from the frontotemporal areas before and after the therapy, was used. 30 female patients with telogen effluvium aged between 20 and 56 years old were recruited for the research and randomly divided into two groups. Patients of group I were treated with lotion based on biomimetic peptides and those of group II were treated with $0.9 \%$ saline. The therapeutic efficacy of biomimetic peptides in women with telogen effluvium was assessed by trichoscopy and phototrichography. A change in the expression of VEGF, KGF, TGF- $\beta 1$ growth factors was found in women with telogen effluvium as opposed to the healthy ones. After the therapy, a significant increase in the VEGF, EGF expression and a decrease in KGF and TGF- $\beta 1$ expression were noted. The study proved the effectiveness of the proposed method of therapy for women with telogenic effluvium. The research findings can be useful to dermatologists and cosmetologists for increasing the effectiveness of therapy for patients with telogenic effluvium. Also, the data obtained in the article open up the prospect for the further study of the pathogenetic mechanisms of telogenic effluvium and provide an opportunity for an innovative approach to the therapy of patients with telogenic effluvium.
\end{abstract}

\section{INTRODUCTION}

Diffuse cyclic hair loss in women has been described for the first time by W. Guy and W. Edmundson in 1960 (Guy and Edmundson, 1960). In 1961, A.M. Kligman introduced the term of telogen effluvium to define a condition that is accompanied by intensified telogen hair loss as a result of hair follicle cycle abnormalities (Kligman, 1961).

A vast number of triggers to induce hair loss were discovered. These include hypo-and hyperthyroidism(Sperling,

*Corresponding Author

Yulia Albertovna Gallyamova; Department of Dermatovenereology and

Cosmetology, Russian Medical Academy of Continuous Professional

Education, 2/1 Barrikadnaya St., Moscow, 123995, Russia.

E-mail: yulya.gallyamova.69@mail.ru
2001), chronic systemic disorders, such as amyloidosis, hepatic failure, chronic renal failure, inflammatory bowel disorders, or lymphoproliferative disease, which may cause telogen effluvium (Kligman, 1961; Fiedler and Gray, 2003). Telogen effluvium is also observed with autoimmune diseases, such as systemic lupus erythematosus or dermatomyositis (Fiedler, 2003), infectious diseases, such as human immunodeficiency virus type 1 (Sperling, 2001), and secondary syphilis (Rook and Dawber, 1982). Chronic skin disorders, such as psoriasis or seborrheic dermatitis, can also cause telogen effluvium (Apache, 1986; Bergfeld, 2008).

A number of drugs are known to lead to hair loss and these include combined oral contraceptives, androgens, retinoids, beta-blockers, anticonvulsants, antidepressants, anticoagulants, antithyroid agents, ACE inhibitors, and lithium medications 
(Fiedler and Gray, 2003; Tosti and Pazzaglia, 2007; Patel et al., 2013; Watras et al., 2016).

Many authors highlight the association between telogen effluvium and deficits of micronutrients, such as zinc, Ferrum, Vitamin D, Vitamin H, etc. (Trüeb, 2016; Cheung et al., 2016). There is research available to prove insufficiency of essential micronutrients (zinc and selenium) and excess of toxic microelements (cadmium, lead, beryllium, and stibium) in those suffering from telogen effluvium (Fiedler and Gray, 2003; Rook and Dawber, 1982; Rushton, 2002; Abdel-Aziz et al., 2015).

The effect of the psychoemotional state on hair loss intensity was mentioned multiple times in last-century publications (Habit, 1990; Pasricha, 1991). Ebling suggested yet back in 1987 that hypothalamic cells that are capable of transforming nerve impulses into hormonal and influence hair follicles indirectly (Ebling, 1987). Modern authors, however, believe these arguments are weak since everyday stress is not enough to cause intensive hair loss (Harrison, 2002; Fiedler, 2003). Despite many publications attaching great importance to psychoemotional stress in telogen effluvium development, this matter is still disputed (Fiedler and Gray, 2003; Rook and Dawber; 1982).

One or another provoking factor affects keratinocyte division and differentiation, metabolic processes in the bulge region of the hair follicle, which leads to premature anagen termination. The hair follicle gradually passes into the phase of the catagen, and then the telogen, the ratio of telogen and anagen hair changes, respectively. This cycle takes a certain period of time, usually about two to four months. Patients notice massive hair fallout in two to four or even six months; therefore, the causality between hair thinning and the etiologic factor is not obvious (Harrison, 2002; Headington, 1993).

The authors believe telogen effluvium to be acute (last up to 6 months), chronic (6 months and more), or chronic with relapses (Bergfeld, 2001; 2008). If the exposure to the triggering factor is short, hair fallout regresses spontaneously or against appropriate treatment. If the pathological effect on the hair follicle lasts for a long time, or different triggering factors are in action by turn, telogen effluvium grows strong (Bergfeld, 2008).

Considering the pathologic mechanism of telogen effluvium, potential therapeutic possibilities include catagen inhibition, which requires anagen prolongation; anagen induction in telogen follicles and exogene suppression in order to stop hairs from falling out. Neither drug that is currently used to treat alopecia is effective in inhibiting catagen or inducing anagen (Paus, 2008).

Today's fundamental cytogenetic and biochemical research highlights the role of regulatory substances in hair cycling. These include growth factor families and receptors, transcription factors, cytokines, neurotrophins, and intracellular signaling pathways. Special consideration is given to polypeptide growth factors that are together referred to as trophic regulatory substances. These factors exert a variety of effects on various cells: stimulate or inhibit cell proliferation chemotaxis, and differentiation. Growth factors capable of regulating the hair growth cycle have been established recently (Takakura, 1996; Yano, 2001; Rishikaysh et al., 2014).

Growth factors are capable of inducing cell proliferation of vascular endothelium and dermal fibroblasts, prolonging anagen and delaying catagen onset in a hair follicle (Böhlen,
1985; Kawano, 2005; Kimura-Ueki et al., 2012). Hence, anagen can be prolonged and hair growth can be stimulated with the help of these growth factors (Ozeki, 2003; Tomita, 2006; Jain and De-Eknamkul, 2014).

Vascular endothelial growth factor (VEGF) is the most studied growth factor. VEGF is of great importance in the development and life of hair. It promotes growth, determines the differentiation, structure, and duration of the hair follicle and hair shaft growth in vivo (Yano, 2001). VEGF exerts a huge impact on vascularization and angiogenesis, thus stimulating hair growth (Ozeki and Tabata, 2003; Bartels et al., 2011; Kim et al., 2013). The study of the mechanisms of apoptosis in the hair follicle has determined the important role of the transforming growth factor (TGF). Many studies have shown that TGF- $\beta$ has unique multidirectional effects on the physiology of the hair follicle - both stimulating and inhibiting effects on hair growth (Stenn, 2001; Inoue, 2009). Controversial data was obtained in the study of the role of epidermal growth factor (EGF) (Cohen, 1963; Moore, 1981; Kashiwagi, 1997) and keratinocyte growth factor (KGF) (Guo and Fuchs, 1993; Danilenko, 1995; Kawano et al., 2005) in the hair cycle. Studies have shown a dose-dependent effect of KGF and EGF on hair growth (Guo and Fuchs, 1993; Danilenko, 1995; Kashiwagi, 1997).

Currently, numerous studies are of experimental nature, and the role of growth factors in the pathogenic mechanism of various types of alopecia and their effect on lesion severity is still undisclosed.

Growth factors are studied not just for theoretical purposes, but out of practical necessity as well. It was established that physiological processes influence just small fragments of growth factors, i.e. oligopeptides, instead of whole molecules. With view to the above, biomimetic peptides have been presently synthesized (Lat. bios - life and mimesis - imitation). They are composed of amino acid residues that are capable of selective interaction with cell receptors and can be used topically (Lupo and Cole, 2007).

We have studied the effect biomimetic peptides have on growth factor expression in a hair follicle and assessed therapeutic efficacy in female patients with telogen effluvium.

\section{MATERIALS AND METHODS}

This study involved 30 female subjects with telogen effluvium at average age of $37.1 \pm 9.29$ years. Eight healthy females at average age of $38.5 \pm 7.4$ years constituted the control group. Inclusion criteria included Informed Consent and age of 18 to 60 years. Exclusion criteria included thyroid disorders, active skin lesions, infectious diseases, hyperandrogenism, severe somatic comorbidities, and other types of alopecia. The study protocol was approved by the Ethical Committee of the Russian Medical Academy of Postgraduate Education. The selected patients were randomly divided into two groups; group I included 15 patients, who were treated with lotion based on biomimetic peptides, and group II included 15 control patients who were treated with $0.9 \%$ saline.

\section{Intervention technique}

A lotion based on biomimetic peptides $(2 \mathrm{ml})$ was topically applied on the scalp of group I patients and followed by microneedle therapy (needle size of $0.2 \mathrm{~mm}$ ) (China, Beijing, 
Beijing Peak Beauty Technology Co., Ltd., Micro Needle Roller System). The patients of group II were treated with normal saline followed by microneedle therapy. The major components of the topical solution used for treatment were: Decapeptide-18, Oligopeptide-54, Decapeptide-10, Octapeptide-2, Decapeptide-19, Oligopeptide-71, and Decapeptide-28. Each patient received 16 treatments at 3-4 days intervals.

\section{Assessment of the response}

Assessment of the response was done two months after treatment commencement and two and six months after the last treatment. Photography Digital photos were taken for the scalp before therapy and during subsequent visits.

Physical examination of the scalp covered the following: assessment of visible hair thinning, thinning of a hair shaft, intensity of sebaceous excretions, and scalp rash, if any. Assessment of hair density, diameter, proportion of vellus and terminal hairs, ratio and distribution of hairs in follicular units, proportion of anagen and telogen hairs in the androgen dependent and androgen independent scalp regions was done for all patients, using a specialized Aramo SG microcamera (Rep. Korea, Seoul, Bundang Seoul National University Hospital Health Care Innovation Park 401-ho, Aram HUVIS Co., Ltd.) in combination with Trichoscience 1.7 application (Russia, Moscow, Trilogic) in the fixed zone, and a permanent mark was made.

\section{Immunofluorescence}

Punch biopsy ( $4 \mathrm{~mm}$ ) was done under local anesthesia in patients with alopecia. For the local anesthesia, the anesthetic lidocaine (Hungary, Budapest, Egis Pharmaceuticals PLC) was administered subcutaneously around the site of biopsy. Parietal bioptates were taken before the treatment. In 2 months, bioptates were taken from the regions in close proximity to the first punch biopsy.

Eight control scalp samples were taken from the patients that did not complain of hair loss and did not present any signs of alopecia during a surgery or other routine intervention for benign lesions, always by voluntary informed consent of the patient.

VEGF, KGF, EGF, and TGF- $\beta 1$ expression was studied by immunofluorescence, using standard technique using antibodies directed against VEGF, KGF, EGF (all UK, Cambridge, Abcam), TGF- $\beta 1$ (UK, Abingdon, Novus Biologicals).

For the assessment of the results, the morphometric research was conducted using the system of computer analysis of microscopic images, which comprised a confocal Olympus FlueView1000 microscope and a personal computer on the basis of Intel Pentium 4, and "Videotest Morphology 5.0" (Russia). The expression of growth factors was assessed in 5 visual fields at magnification of x 200 .

\section{Statistical analysis}

A statistical analysis was performed using $\mathrm{R}$ version v3.2.0. The Shapiro-Wilk test was used to determine patient distribution by parameter values. Descriptive statistic values were calculated, using standard techniques. If distribution of quantitative parameters was recognized normal, mean deviation and standard deviation were calculated. If the distribution deviated from normal, median and quartiles were calculated. Mode and $25-75 \%$ quartiles were calculated for qualitative parameters. The Wilcoxon test was used for time comparison before and after the treatment with $\mathrm{p}<0.05$. The null hypothesis for the groups was rejected.

\section{RESULTS}

Under our supervision, there were 30 patients with the diagnosis of telogen effluvium and the average age of the patients was $37.1 \pm 9.29$ years old, average age of disease onset was 26 (22-33.25) years old, and the average disease duration was 5 (1.25-16) years.

According to patient histories, the patients associated their disease onset with childbirth $(n=6 ; 20 \%)$, or stress $(n=12$; $40 \%$ ), and one patient mentioned diet deviation $(\mathrm{n}=1 ; 3.33 \%)$. Eleven women $(36.67 \%)$ were not able to associate their disease onset with any certain provoking factor. It was determined from family histories that eleven (30\%) patients with telogen effluvium had hereditary diseases, passed by their father: ten $(33.33 \%)$, passed by their mother: four (13.33\%), including both mother and father (in three patients), all by first relation degree.

The majority of patients used self-treatment with topical hair products and oral medicines: 13 (43.33\%) and 10 (33.33\%), respectively. A variety of lotions and shampoos, folk remedies were used topically, and combined vitamins and minerals were taken orally. Among them, seven patients (23.30\%) underwent mesotherapy. Despite their treatment, temporary effect was observed in $4(21 \%)$ patients, and no positive changes were found in $11(57.89 \%)$ of patients with telogen effluvium. Eleven $(36.67 \%)$ patients among the studied women did not receive any treatment.

\section{Trichoscopy and phototrichography assessment}

According to trichoscopy and phototrichography, normal ratio of anagen and telogen hairs was observed in the patients before treatments towards the increased proportion of telogen hairs. At the same time, the number of hairs per square centimeter, ratio of terminal and vellus hairs in the parietal and occipital regions was within normal.

Following the combined treatment, there was observed a statistically significant increased proportion of anagen hairs in group I (from $62.98 \pm 11.26 \%$ to $82.09 \pm 10.18 \%$ and from $75.51 \pm$ $6.52 \%$ to $85.77 \pm 6.08 \%$, respectively) and a statistically significant decreased proportion of telogen hairs (from $37.02 \pm 11.26 \%$ to 17.64 $\pm 10.09 \%$ and from $24.49 \pm 6.52 \%$ to $14.23 \pm 6.08 \%$, respectively), juvenile hairs also emerged in the parietal region. Positive changes were observed 2 and 6 months after treatment (Table 1).

Therefore, a statistically significant increase in total number of hairs per square centimeter in the parietal region, decrease in the proportion of telogen hairs and increase in the proportion of anagen hairs, and a statistically significant increase in the hair diameter in the parietal and occipital regions were observed, when comparing trichoscopy and phototrichography data for group I patients with telogen effluvium before and after treatment $(p<0.05)$. A statistically significant increase in the total number of hairs and follicular units per square centimeter of the parietal region was observed, when comparing trichoscopy and phototrichography data before treatment and 2 months after treatment. 
Table 1: Trichoscopy and phototrichogram analysis before and after treatment.

\begin{tabular}{|c|c|c|c|c|c|c|c|c|c|}
\hline \multirow[b]{2}{*}{ Localization } & \multirow[b]{2}{*}{ Parameter } & \multicolumn{4}{|c|}{$\operatorname{group} I(n=15)$} & \multicolumn{4}{|c|}{ group II $(n=15)$} \\
\hline & & $\begin{array}{l}\text { before treat- } \\
\text { ment }\end{array}$ & $\begin{array}{c}\text { after } \\
\text { treatment }\end{array}$ & $\begin{array}{c}2 \text { months after } \\
\text { treatment }\end{array}$ & $\begin{array}{c}6 \text { months after } \\
\text { treatment }\end{array}$ & $\begin{array}{l}\text { before } \\
\text { treatment }\end{array}$ & $\begin{array}{l}\text { after treat- } \\
\text { ment }\end{array}$ & $\begin{array}{c}2 \text { months after } \\
\text { treatment }\end{array}$ & $\begin{array}{c}6 \text { months after } \\
\text { treatment }\end{array}$ \\
\hline \multirow{7}{*}{$\begin{array}{l}\text { Androgen-dependent } \\
\text { (parietal) region }\end{array}$} & $\begin{array}{c}\text { Hair density } \\
\text { [number of } \\
\text { hairs per sq.cm] }\end{array}$ & $\begin{array}{l}242.4(231.9- \\
289.6)\end{array}$ & $\begin{array}{c}289.65 \pm \\
82.551\end{array}$ & $303.22 \pm 87.7^{2}$ & $\begin{array}{c}289.2(243.7- \\
334.4)^{3,4}\end{array}$ & $\begin{array}{l}310.85 \pm \\
86.75\end{array}$ & $310.87 \pm 88.58$ & $321.31 \pm 85.94^{2}$ & $320.09 \pm 88.68^{4}$ \\
\hline & $\begin{array}{l}\text { [follicular units } \\
\text { per sq.cm] }\end{array}$ & $\begin{array}{c}165.7(124.4- \\
179.5)\end{array}$ & $\begin{array}{c}168.07 \pm \\
54.44\end{array}$ & $181.86 \pm 57.15^{2}$ & $\begin{array}{c}188.37 \pm \\
66.144\end{array}$ & $\begin{array}{l}197.75 \pm \\
53.98\end{array}$ & $191.64 \pm 63.3$ & $188.91 \pm 55.79$ & $196.71 \pm 57.94$ \\
\hline & $\begin{array}{l}\text { average hair } \\
\text { diameter }[\mu \mathrm{m}]\end{array}$ & $66 \pm 8.57$ & $80(73-80)^{1}$ & $77(66 ; 77.5)$ & $72.73 \pm 12.67$ & $63.13 \pm 7.47$ & $65.87 \pm 8.98^{1}$ & $65(62-69)$ & $64(59-67.5)^{3}$ \\
\hline & $\begin{array}{c}\text { anagen hairs } \\
{[\%]}\end{array}$ & $62.98 \pm 11.26$ & $\begin{array}{c}82.09 \pm \\
10.18^{1}\end{array}$ & $85.95 \pm 4.08$ & $\begin{array}{l}89.1(85.1- \\
90.1)^{3,4}\end{array}$ & $\begin{array}{c}64.09 \pm \\
12.01\end{array}$ & $72.84 \pm 5.77^{1}$ & $81.87 \pm 4.2^{2}$ & $82.05 \pm 4.98^{4}$ \\
\hline & $\begin{array}{c}\text { Telogen hairs } \\
{[\%]}\end{array}$ & $37.02 \pm 11.26$ & $\begin{array}{c}17.64 \pm \\
10.09^{1}\end{array}$ & $12.67 \pm 4.03$ & $10.9(9.9-14.9)^{4}$ & $\begin{array}{c}35.91 \pm \\
12.01\end{array}$ & $27.16 \pm 5.63^{1}$ & $18.13 \pm 4.2^{2}$ & $17.95 \pm 4.98^{4}$ \\
\hline & juvenile [\%] & 0 & 0 & $0(0-1.1)$ & 0 & 0 & 0 & 0 & 0 \\
\hline & $\begin{array}{l}\text { vellus hairs [\%] } \\
\qquad(<30 \mu \mathrm{m})\end{array}$ & $12(6-16)$ & $\begin{array}{c}11.93 \pm \\
5.71\end{array}$ & $7.93 \pm 5.32^{2}$ & $39.6 \pm 1.78$ & $13 \pm 6.15$ & $12.4 \pm 5.78$ & $6(4-15.5)^{2}$ & $9(3-10)$ \\
\hline \multirow{6}{*}{$\begin{array}{l}\text { Androgen-independent } \\
\text { (occipital) region }\end{array}$} & $\begin{array}{c}\text { Hair density } \\
\text { [number of } \\
\text { hairs per sq.cm] }\end{array}$ & $\begin{array}{c}242.75 \pm \\
34.81\end{array}$ & $\begin{array}{c}249.75 \pm \\
41.89\end{array}$ & $\begin{array}{l}220.9(210.95- \\
267.6)\end{array}$ & $252.62 \pm 52.35$ & $\begin{array}{c}275.5 \\
(217.5- \\
276.9)\end{array}$ & $\begin{array}{l}269.6(228.55- \\
280.25)\end{array}$ & $241.89 \pm 47.29$ & $248.07 \pm 41.98^{3}$ \\
\hline & $\begin{array}{l}\text { [follicular units } \\
\text { per sq.cm] }\end{array}$ & $\begin{array}{c}115.3(105.9- \\
172.2)\end{array}$ & $\begin{array}{c}124.6 \\
(108.15- \\
167)\end{array}$ & $135.27 \pm 44.74$ & $139.8(59.08)$ & $\begin{array}{c}137.59 \pm \\
36.5\end{array}$ & $133.05 \pm 50.55$ & $142.05 \pm 51.11$ & $147.4 \pm 44.97$ \\
\hline & $\begin{array}{l}\text { Average hair } \\
\text { diameter }[\mu \mathrm{m}]\end{array}$ & $61 \pm 9.33$ & $\begin{array}{c}71(68.5- \\
75.5)^{1}\end{array}$ & $73(72-75)$ & $72(67-75.5)^{4}$ & $61.53 \pm 8.02$ & $63.87 \pm 6.63$ & $63.27 \pm 7.89$ & $65.93 \pm 6.86^{4}$ \\
\hline & $\begin{array}{c}\text { anagen hairs } \\
{[\%]}\end{array}$ & $75.51 \pm 6.52$ & $\begin{array}{c}85.77 \pm \\
6.08^{1}\end{array}$ & $89.44 \pm 5.97$ & $89.11 \pm 3.82^{4}$ & $\begin{array}{c}75.9(69.55- \\
78.6)\end{array}$ & $\begin{array}{c}80.4(77.25- \\
81.7)^{1}\end{array}$ & $84.07 \pm 4.35^{2}$ & $84.39 \pm 2.26^{4}$ \\
\hline & $\begin{array}{c}\text { Telogen hairs } \\
{[\%]}\end{array}$ & $24.49 \pm 6.52$ & $\begin{array}{c}14.23 \pm \\
6.08^{1}\end{array}$ & $10.56 \pm 5.97$ & $10.89 \pm 3.82^{4}$ & $\begin{array}{c}24.1(21.4- \\
30.45)\end{array}$ & $\begin{array}{c}19.6(18.3- \\
22.75)^{1}\end{array}$ & $15.93 \pm 4.35^{2}$ & $15.61 \pm 2.26^{4}$ \\
\hline & $\begin{array}{l}\text { Vellus hairs } \\
{[\%](<30 \mu \mathrm{m})}\end{array}$ & $12.6 \pm 7.31$ & $13 \pm 8.4$ & $6(2.5-12)^{2}$ & $8(4.5-13)$ & $14 \pm 5.45$ & $13.33 \pm 8.25$ & $10.4 \pm 5.95$ & $10.73 \pm 7.27$ \\
\hline
\end{tabular}

Values are mean (SD) or median and range.

${ }^{1}$ statistically significant differences between parameters before and after treatment in each group; $\mathrm{P}<0.05$

${ }^{2}$ statistically significant differences between parameters after treatment and 2 months after treatment in each group; P $<0.05$

${ }^{3}$ statistically significant differences between parameters 2 months after treatment and 6 months after treatment in each group; $\mathrm{P}<0.05$

${ }^{4}$ statistically significant differences between parameters before treatment and 6 months after treatment in each group; $\mathrm{P}<0.05$.

A statistically significant increase in the total number of hairs by $19.3 \%$ and follicular units per square centimeter by $13.7 \%$ in the parietal region, a statistically significant increase in the proportion of anagen hairs in the parietal region (by $26.12 \%$ ) and

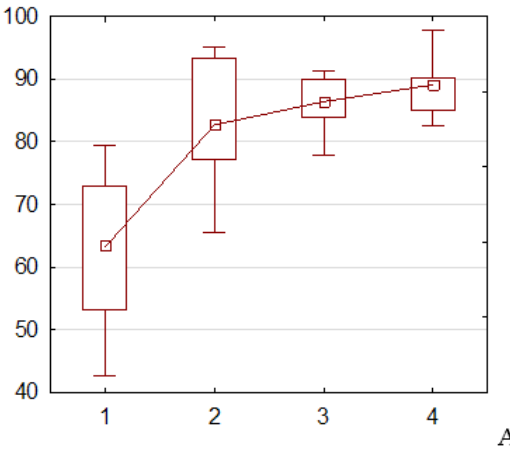

occipital region (by 13.6\%), and a statistically significant increase in the diameter of hairs in the occipital region were established, when comparing trichoscopy and phototrichography data before treatment and 6 months after treatment $(\mathrm{p}<0.05)$ (Table 1$)$.

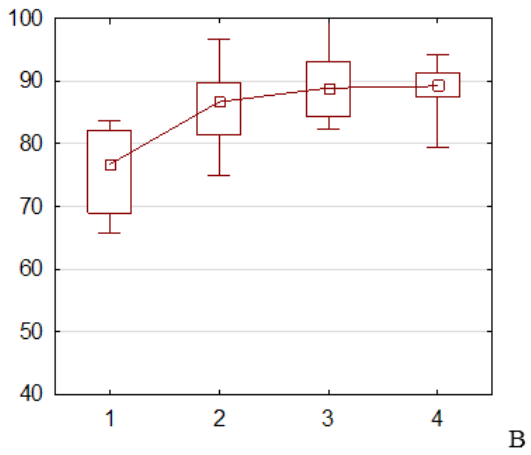

Fig. 1: Changes in anagen hairs in the parietal region (A) and occipital region (B) in group I patients against treatment.

Note: rectangles correspond to margins of $25 \%$ and $75 \%$ quartiles, black horizontal lines correspond to median. Time intervals are represented on the X-axis: before treatment (1), after treatment (2), 2 months after treatment (3), 6 months after treatment (4); proportion of anagen hairs (\%) is represented on Y axis. 


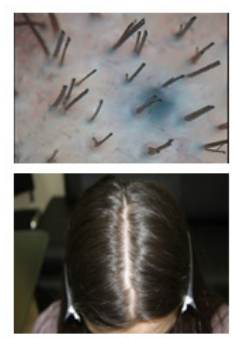

A

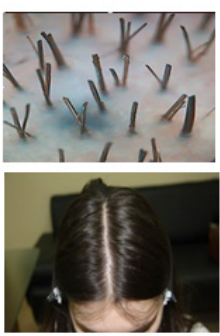

B

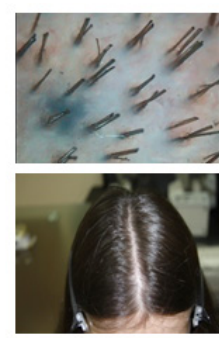

$\mathrm{C}$

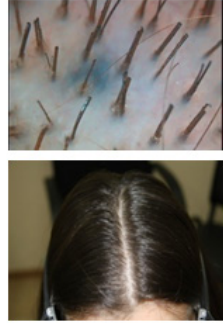

$\mathrm{D}$

Fig. 2: Phototrichogram and panoramic photo before treatment (A), after treatment (B), two months after treatment (C), and six months after treatment (D).

According to our comparative analysis, the proportion of anagen hairs increased statistically signicant by $26.12 \%$ in the parietal region and by $13.6 \%$ in the occipital region in group I patients, as a result of treatment. Furthermore, the effect of this therapy was long lasting and retained 6 months after the treatment. The proportion of growing hairs statistical increased by $8.5 \%$ more in the parietal region and by $3.9 \%$ more in the occipital region for this period of time (Table 1, Fig. 1, 2).

A statistical increase of anagen hairs in the parietal and occipital regions (from $64.09 \pm 12.01$ to $72.84 \pm 5.77$ and from 75.9 (69.55-78.6) to 80.4 (77.25-81.7), respectively) was observed in group II patients after treatment. Positive changes were observed 2 and 6 months after treatment.

A statistically significant decrease in the proportion of telogen hairs and statistical increase in the proportion of anagen hairs in the parietal and occipital regions, and statistical increase in the hair diameter in the parietal region were observed, when comparing trichoscopy and phototrichography data in group II patients before and after treatment. Comparison of total number of hairs per square centimeter, follicular units per square centimeter

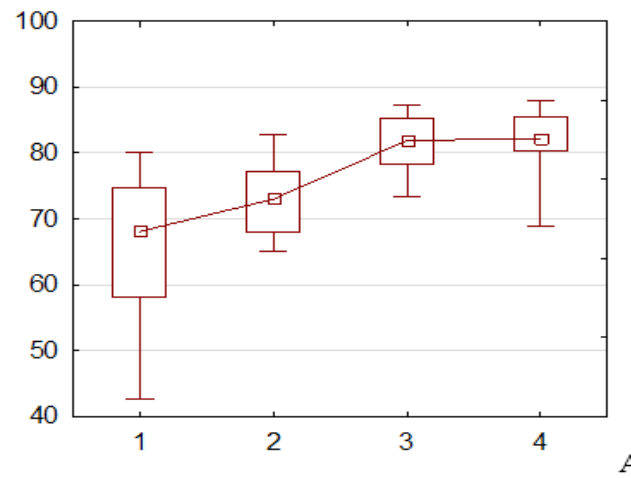

in the parietal and occipital regions, and hair diameter before and after treatment in the parietal region did not produce any statistically significant differences (Table 1).

Despite positive changes against treatment in group II patients (Fig. 3), phototrichography data did not reach normal parameter values in the majority of group II patients and were statistical significantly lower vs. the experimental group (Table 1 ), while the proportion of anagen hairs statistical increased by $17.96 \%$ in the parietal region and by $8.49 \%$ in the occipital region.

\section{VEGF, KGF, EGF, and TGF- $\beta 1$ expression assessment}

Relative VEGF expression area was $68.53 \pm 1.08 \%$ in healthy patients. VEGF expression was significantly lower on the scalp of group I and group II patients vs. healthy patients (26.91 \pm 0.66 and $26.1(25.57-26.88) \%$, respectively). A significant increase in VEGF expression on the scalp of group I patients was observed after treatment up to $32.26(32.22-32.84) \%(\mathrm{p}<0.05)$; therefore, VEGF expression increased by $19.8 \%$. An increase in VEGF expression merely by $2.8 \%$ (Table 2 ) was observed in the control group.

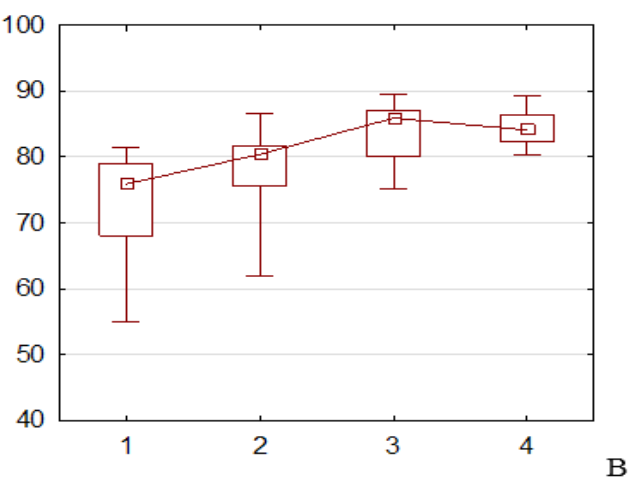

Fig. 3: Changes in anagen hairs in the parietal region (A) and occipital region (B) in group II patients against treatment.

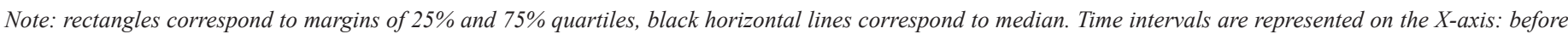
treatment (1), after treatment (2), 2 months after treatment (3), 6 months after treatment (4); proportion of anagen hairs (\%) is represented on Y axis.

Relative KGF expression area on the scalp of healthy patients was $47.68 \pm 0.93$. KGF expression was significantly lower on the scalp of group I and group II patients vs. healthy patients $(35.65 \pm 0.63 \%$ and $36 \pm 0.75 \%)$. KGF expression on the scalp of group I patients with telogen effluvium decreased by $28 \%$ after treatment $(\mathrm{p}<0.05)$. An increase in KGF expression by $2.8 \%$ was observed in the control group (Table 2).
Relative EGF expression area was $19.96 \pm 3 \%$ in healthy patients. Level of EGF expression in women of the I and II group $(18.89 \pm 0.46 \%$ and $19.8(19.19-20.24) \%$, respectively) did not differ from the healthy values $(\mathrm{p}=0.830)$. After treatment, EGF expression increased in group I patients by $27.66 \pm 0.6 \%$ (p< $0.05)$, and an increase in EGF expression was also observed in group II patients EGF $(21.37(20.32-22.67) \%)(p<0.05)($ Table 2$)$. 
Table 2: Growth factor expression in patients with telogen effluvium (group I and II) before and after treatment.

\begin{tabular}{|c|c|c|c|c|c|c|c|c|}
\hline \multirow{3}{*}{ Parameter } & \multicolumn{2}{|c|}{ VEGF } & \multicolumn{2}{|c|}{ KGF } & \multicolumn{2}{|c|}{ EGF } & \multicolumn{2}{|c|}{ TGF- $\beta 1$} \\
\hline & Before treatment & After treatment & Before treatment & After treatment & Before treatment & After treatment & Before treatment & After treatment \\
\hline & \multicolumn{8}{|c|}{ Relative expression area [\%] } \\
\hline Group I & $26.91 \pm 0.66$ & $\begin{array}{c}32.26(32.22- \\
32.84)^{*}\end{array}$ & $35.65 \pm 0.63$ & $25.59 \pm 0.83^{*}$ & $18.89 \pm 0.46$ & $27.66 \pm 0.6^{*}$ & $64.67 \pm 0.51$ & $52.97 \pm 0.65^{*}$ \\
\hline Group II & $\begin{array}{c}26.1(25.57- \\
26.88)\end{array}$ & $26.83 \pm 2.15^{*}$ & $36 \pm 0.75^{*}$ & $37 \pm 0.83^{*}$ & $\begin{array}{c}19.8(19.19- \\
20.24)\end{array}$ & $\begin{array}{c}21.37(20.32- \\
22.67)^{*}\end{array}$ & $64 \pm 0.86$ & $55.27 \pm 2.14^{*}$ \\
\hline
\end{tabular}

Values are mean $(\mathrm{SD})$ or median and range. *- statistically significant differences: $\mathrm{p}<0.05$.

Relative TGF- $\beta 1$ expression area on the scalp of healthy patients was $51.72 \pm 2.21 \%$. Study of TGF- $\beta 1$ changes on the scalp of group I and II patients, showed a significant decrease in TGF- $\beta 1$ expression by $18.1 \%$ and $13.6 \%$, respectively $(\mathrm{p}<0.05)$ (Table 2).

\section{DISCUSSION}

With this study, we determined that biomimetic peptides are safe, as topical application followed by microneedle therapy. Subjectively the patients tolerated the treatment well, no side effects were identified, and none of the patients were excluded from the observation group. After the end of treatment, the withdrawal syndrome was not observed.

The analysis of the trichoscopy and phototrichogram indices in the parietal and occipital regions (hair density, the number of follicular units per square centimeter, the percentage of hair in the anagen stage, the hair diameter) before treatment, after treatment and in two and six months after treatment showed a statistically significant greater increase in the percentage of the hair in the anagen stage in female patients of the main group, compared to the control group. In patients treated with biomimetic peptides, the percentage of the anagen and the telogen hair reached of the normal values.

In addition, the patients of the main group had a statistically significant increase in follicular units in the parietal region. These data indicate that the application of biomimetic peptides in patients with telogen effluvium leads to a decrease in hair loss due to stimulation and prolongation of the anagen phase and, consequently, reduction of the telogen phase. Initiation of the anagen stage is confirmed by the objective fact of the appearance of young hair, increase in the percentage of hair in the anagen stage against the background of the increase in the total amount of hair; and the increase in the number of follicular units during the treatment period indicates the extension of the anagen period. In both groups, throughout the entire observation period, the increase in the hair diameter in the parietal and occipital areas was noted, indicating that the increase in hair thickness was affected to a greater extent by mechanical exposure of the dermoroller.

The analysis of growth factor expression showed a change in VEGF, KGF, and TGF- $\beta 1$ growth factors in female patients with telogen effluvium vs. healthy female population. This study established that VEGF, KGF, and TGF- $\beta 1$ expression in a hair follicle was impaired in patients with telogen effluvium. EGF expression was equivalent in these patients and healthy women and did not differ statistically.

Biomimetic peptide treatment efficacy in telogen effluvium patients has been assessed for the first time in this study.
It was established earlier that VEGF regulates hair growth by interacting with the VEGFR-2 receptor (Man, 2009; Wu, 2014). The VEGFR-2 receptor is located in human hair follicles (including bulge in a dermal papilla), sebaceous glands, eccrines, and other cells. It has been known that high VEGF mRNA expression in the dermal papillary cells is registered in anagen.

Animal experiments demonstrated perifolicular vessels enlarging by more than four times in anagen, which coincides with cyclic follicle size change. At the same time, the perifolicular angiogenesis correlates with activated VEGF mRNA expression in folicular keratinocytes of the outer root sheath. All the above allowed the authors to suggest improved vascularization and increased hair follicle size in the experimental animals to be associated directly with VEGF mRNA expression (Yano, 2001). It was also established that VEGF mRNA count in a hair follicle normally varies along the hair cycle: it increases in anagen and decreases in catagen and telogen (Man, 2009). A significant increase of $19.8 \%$ in VEGF expression on the scalp was observed after treatment in patients treated with biomimetic peptides, while an increase of $2.8 \%$ in VEGF expression was observed in the control group.

Increased EGF expression on the scalp of telogen effluvium patents was observed in the experimental and control group as a result of the treatment. Investigation of EGF in the hair cycle generated conflicting data, since P.J. Miettinen et al., H. Zhang et al. assumed EGF importance in hair follicle development and hair growth (Miettinen, 1995; Zhang et al., 2016a; Zhang et al., 2016b). Kashiwagi et al., Richardson et al. showed dose and time dependent EGF effect on hair growth, using an animal model (Kashiwagi et al., 1997; Richardson, 2009).

A significant decrease in TGF- $\beta 1$ expression on the scalp was observed after treatment in patients treated with biomimetic peptides by $18.1 \%$ vs. $13.6 \%$ in the control group. The study of apoptosis mechanisms in a hair follicle determined an importance of the transforming growth factor (TGF- $\beta$ ). K. Foitzik and X. Liu with their colleagues determined on an animal model that TGF- $\beta 1$ inhibits hair growth by shortening anagen and initiating follicle catagen. The dependence of TGF- $\beta 1$ expression on the hair follicle phase was also shown (Foitzik et al., 2000; Liu et al., 2001; Lu et al., 2016).

The KGF's expression on the scalp of the patients that were treated with biomimetic peptides lowered by $28 \%$, while an increase in the expression by $2.8 \%$ was observed in the control group. D.M. Danilenko, et al., Richardson G.D., et al., and L.Guo, et al., showed the effect of the keratinocyte growth factor (KGF) to depend on the dose and either to induce, or inhibit hair growth. KGF is necessary for normal growth, development, 
and differentiation of a hair follicle, while it binds to the KGFR receptor (Guo et al., 1993; Danilenko, 1995; Richardson et al., 2009).

\section{CONCLUSION}

Therefore, the following may be concluded that, the use of biomimetic peptide treatment improves perifolicular vascularization, which leads to improved blood flow and intensifies hair growth.

While TGF- $\beta$ is a powerful growth inhibitor of different cell types, including majority of epithelial cells, a decrease in TGF- $\beta$ expression following biomimetic peptide treatment indicates lower apoptosis in patients after treatment, as compared with the sample before treatment.

According to the research findings, the role KGF and EGF growth factors in alopecia development is poorly studied, and their ambiguous expression can be associated with some unknown molecular signaling mechanisms.

The authors have analyzed phototrichographys parameters and concluded that telogen effluvium patients experience reduced hair thinning due to anagen stimulation and prolongation and, respectively, telogen shortening. Anagen initiation is objectively evidenced by the juvenile hairs present and the increased number of units over the treatment period indicates anagen prolongation.

\section{CONFLICT OF INTERESTS}

There are no conflicts of interest.

\section{FINANCIAL SUPPORT AND SPONSORSHIP}

Nil.

\section{ABBREVIATIONS}

$\begin{array}{ll}\text { VEGF } & \text { Vascular endothelial growth factor } \\ \text { KGF } & \text { Keratinocyte growth factor } \\ \text { EGF } & \text { Epidermal growth factor } \\ \text { TGF- } \beta 1 & \text { Transforming growth factor beta } 1 \\ \text { VEGFR } & \text { Vascular endothelial growth factor receptor } \\ \text { KGFR } & \text { Keratinocyte growth factor receptor. }\end{array}$

\section{REFERENCES}

Abdel-Aziz AM, Hamed SS, Gaballah MA. Possible Relationship between Chronic Telogen Effluvium and Changes in Lead, Cadmium, Zinc, and Iron Total Blood Levels in Females: A Case-Control Study. Int J Trichology. 2015; 7(3):100-106.

Apache PG. Eczematous dermatitis of the scalp. 1986. In: Zviak C, ed. The Science of Hair Care. New York, NY: Marcel Dekker, 513-521.

Bartels NG, Jahnke I, Patzelt A, et al. Hair shaft abnormalities in alopecia areata evaluated by optical coherence tomography. Skin Res Technol. 2011; 17:201-205.

Bergfeld WF, Mulinari-Brenner F. Shedding: how to manage a common cause of hair loss. Cleve Clin J Med. 2001; 68:256-261.

Bergfeld WF. 2008. Telogen effluvium. In: McMichael J, Hordin MK, eds. Hair and Scalp Diseases: Medical, Surgical, and Cosmetic Treatments. London, UK: Informa Health Care. pp. 119-136.

Watras MM, Patel JP, Arya R. Traditional Anticoagulants and Hair Loss: A Role for Direct Oral Anticoagulants? A Review of the
Literature. Drugs Real World Outcomes. 2016; 3(1):1-6.

Böhlen P, Esch F, Baird A, et al. Acidic fibroblast growth factor (FGF) from bovine brain: amino-terminal sequence and comparison with basic FGF. EMBO J, 1985; 4: 1951-1956.

Cheung EJ, Sink JR, English Iii JC. Vitamin and Mineral Deficiencies in Patients With Telogen Effluvium: A Retrospective CrossSectional Study. J Drugs Dermatol. 2016;15(10):1235-1237.

Cohen S, Elliot GA. The stimulation of epidermal keratinization by a protein isolated from the submaxillary gland of the mouse. J. Invest. Dermatol. 1963; 40:1-5.

Danilenko DM, Ring BD, Yanagihara D, et al. Keratinocyte growth factor is an important endogenous mediator of hair follicle growth, development, and differentiation. Normalization of the $\mathrm{nu} / \mathrm{nu}$ follicular differentiation defect and amelioration of chemotherapy-induced alopecia. Am J Pathol. 1995; 147:145-154.

Ebling FJG. The biology of hair. Dermatol Clin. 1987; 5:467-81.

Fiedler VC, Gray AC. 2003. Diffuse alopecia: telogen hair loss. In: Olsen EA, ed. Disorders of Hair Growth: Diagnosis and Treatment. 2nd ed. New York, NY: McGraw-Hill Publishing. pp. 303-320.

Foitzik K, Lindner G, Mueller-Roever S, et al. Control of murine hair follicle regression (catagen) by TGF-betal in vivo. FASEB J. 2000; 14(5):752-60.

Guo L, Yu QC, Fuchs E. Targeting expression of keratinocyte growth factor to keratinocytes elicits striking changes in epithelial differentiation in transgenic mice. EMBO J. 1993; 12:973-986.

Guy WB, Edmundson WF. Diffuse cyclic hair loss in women. Arch Dermatol, 1960; 81:205-207.

Habit TB. 1990. Hair diseases Clinical Dermatology. Second ed, Mosby Publishers, St Louis 598-615.

Harrison S, Sinclair R. Telogen effluvium. Clin Exp Dermatol. 2002; 27:389-395.

Headington JT. Telogen effluvium. New concepts and review. Arch Dermatol. 1993; 129(3):356-363.

Inoue $\mathrm{K}$, Aoi $\mathrm{N}$, Yamauchi $\mathrm{Y}$, et al. TGF- $\beta 2$ is specifically expressed in human dermal papilla cells and modulates hair folliculogenesis. J Cell Mol Med. 2009; 11-12(13):4643-4656.

Kashiwagi M, Kuroki T, Huh N. Specific inhibition of hair follicle formation by epidermal growth factor in an organ culture of developing mouse skin. Dev Biol. 1997; 189(1):22-32.

Kawano M, Komi-Kuramochi A, Asada M, et al. Comprehensive analysis of FGF and FGFR expression in skin: FGF18 is highly expressed in hair follicles and capable of inducing anagen from telogen stage hair follicles. Journal of Investigative Dermatology. 2005; 124:877-85.

Kim MJ, Lim C, Lee JY, et al. Visible-to-near IR quantum dotbased hypermulticolor high-content screening of herbal medicines for the efficacy monitoring of hair growth promoting and hair loss inhibition. $\mathrm{J}$ Biomol Screen. 2013; 18:462-73.

Kimura-Ueki M, Oda Y, Oki J, et al. Hair cycle resting phase is regulated by cyclic epithelial FGF18 signaling. J Invest Dermatol. 2012; 132:1338-1345.

Kligman AM. Pathological dynamics of human hair loss: telogen effluvium. Arch Dermatol.1961; 83:175-198.

Liu X, Alexander V, Vijayachndra $\mathrm{K}$, et al. Conditional epidermal expression of TGF beta 1 blocks neonatal lethality but causes a reversible hyperplasia and alopecia. Proc Natl Acad Sci USA. 2001; 31, 98(16):9139-44.

Lu GQ, Wu ZB, Chu XY, Bi ZG, Fan WX. An investigation of crosstalk between $W n t / \beta$-catenin and transforming growth factor- $\beta$ signaling in androgenetic alopecia.Medicine (Baltimore). 2016 Jul;95(30):e4297.

Lupo MP, Cole AL. Cosmeceuticalpeptides. Dermatol Ther. 2007 Sep-Oct; 20(5):343-9.

Man XY, Yang XH, Cai SQ, et al. Expression and localization of vascular endothelial growth factor and vascular endothelial growth factor receptor-2 in human epidermal appendages: a comparison study by immunofluorescence. Clin Exp Dermatol. 2009; 34:396-401.

Messenger AG, de Berker DAR, Sinclair RD. 2010. Disorders of 
Hair. In: Rook's Textbook of Dermatology. 8th ed. Oxford, UK: Blackwell Science Publications 66.1-66.16.

Miettinen PJ, Berger JE, Meneses J, et al. Epithelial immaturity and multiorgan failure in mice lacking epidermal growth factor receptor. Nature. 1995; 376:337-341.

Moore GP, Panaretto BA, Robertson D. Effects of epidermal growth factor on hair growth in the mouse. J Endocrinol. 1981; 88(2):293-9.

Ozeki M, Tabata Y. In vivo promoted growth of mice hair follicles by the controlled release of growth factors. Biomaterials. 2003; 24:2387-2394.

Pasricha JS. 1991. Treatment of Skin Diseases. 4th ed, Oxford and IBH Publishers, New Delhi.pp. 220-32.

Patel M, Harrison S, Sinclair R. Drugs and hair loss. Dermatol Clin. 2013; 31(1):67-73.

Paus R, Olsen EA, Messenger AG. 2008. Hair growth disorders. In: Wolff K, Goldsmith LA, Katz SI, Gilchrest BA, Paller AS, Leffell DJ, editors. Fitzpatrick's Dermatology in General Medicine. 7th ed. USA; The McGraw-Hill Companies Inc. pp. 753-777.

Rishikaysh P, Dev K, Diaz D, Qureshi WMS, Filip S, Mokry J. Signaling Involved in Hair Follicle Morphogenesis and Development. Int J Mol Sci. 2014; 15(1):1647-1670.

Richardson GD, Bazzi H, Fantauzzo KA, Waters JM, Crawford H, Hynd P, Christiano AM, Jahoda CA. KGF and EGF signalling block hair follicle induction and promote interfollicular epidermal fate in developing mouse skin. Development. 2009; 136:2153-2164.

Rook A, Dawber R. 1982. Diffuse alopecia: endocrine, metabolic and chemical influences on the follicular cycle. In: Rook A, Dawber R, eds. Diseases of the Hair and Scalp. Oxford, UK: Blackwell Science Publications, 115-145.

Jain R, De-Eknamkul W. Potential targets in the discovery of new hair growth promoters for androgenic alopecia. Expert Opin. Ther. Targets. 2014; 18(7).

Rushton DH. Nutritional factors and hair loss. Clin Exp Dermatol. 2002; 27:396-404.

Sperling LC. Hair and systemic disease. Dermatol Clin. 2001;
19:711-726.

Stenn KS, Paus R. Controls of hair follicle cycling. Physiol Rev, 2001; 81:449-94.

Takakura N, Yoshida H, Kunisada T, et al. Involvement of platelet-derived growth factor receptor-alpha in hair canal formation. J Invest Dermatol. 1996; 107(5):770-7.

Tomita Y, Akiyama M, Shimizu H. PDGF isoforms induce and maintain anagen phase of murine hair follicles. J Dermatol Sci. 2006; 43:105-115.

Tosti A, Pazzaglia M. Drug reactions affecting hair: diagnosis. Dermatol Clin. 2007; 25:223-231.

Trüeb RM. Serum Biotin Levels in Women Complaining of Hair Loss. Int J Trichology. 2016 Apr-Jun; 8(2):73-7.

$\mathrm{Wu} \mathrm{XJ}$, et al. VEGF165 modulates proliferation, adhesion, migration and differentiation of cultured human outer root sheath cells from central hair follicle epithelium through VEGFR-2 activation in vitro. J Dermatol Sci. 2014; 73(2):152-60.

Yano K, Brown LF, Detmar M. Control of hair growth and follicle size by VEGF-mediated angiogenesis. J Clin Invest. 2001; 107:40917.

Zhang H, Nan W, Wang S, et al. Epidermal growth factor promotes proliferation and migration of follicular outer root sheath cells via Wnt/ $\beta$-catenin signaling. Cell Physiol Biochem.; 2016a; 39(1):360-370.

Zhang H, Nan W, Wang S. et al. Epidermal growth factor promotes proliferation of dermal papilla cells via Notch signaling pathway. Biochimie, 2016b; 127:10-8.

How to cite this article:

Kubanov AA, Gallyamova YA, Korableva OA. A Randomized Study of Biomimetic Peptides Efficacy and Impact on the Growth Factors Expression in the Hair Follicles of Patients with Telogen Effluvium. J App Pharm Sci, 2018; 8(04): 015-022. 